\title{
Aesthetic and functional rehabilitation of a supernumerary peg-shaped tooth in the primary dentition
}

\author{
Reabilitação funcional e estética em dente supranumerário conóide na dentição decídua
}

\author{
Débora KOURI ${ }^{1}$ \\ Carla Andréia Veiga BERTAIA \\ Rossimary Coelho de Freitas SANTOS \\ Patrícia Xavier da COSTA-NOBRE \\ Eliane Silveira GARCIA-LEITE ${ }^{1}$ \\ Fernando Borba de ARAUJO2 \\ Gisele Pedroso $\mathrm{MOI}^{1,3}$
}

\begin{abstract}
Supernumerary teeth are common changes in the human dentition that can compromise a congruous dental and facial growth and development. Early diagnosis and proper treatment of these developmental changes are essential for establishing occlusal, functional, and aesthetic congruence. Thus, this article reports the functional and aesthetic rehabilitation of a supernumerary peg-shaped tooth located in the anterior maxillary region of a preschooler. The tooth was restored directly using nanocomposite resin system, a putty index of the incisal position, and modified cotton roll isolation. This minimally invasive procedure not only allows future adjustment but also perfect control of the rehabilitation and simultaneous reestablishment of the child's self-esteem and tooth aesthetics and function. However, treatment should not be limited to the restorative technique. Maintenance of oral health and arch integrity are essential for the correct transition between the primary and permanent dentitions, preventing the treatment from affecting the permanent dentition.
\end{abstract}

Keywords: Deciduous tooth. Dental aesthetics. Mouth rehabilitation. Supernumerary tooth.

\section{RESUMO}

As anomalias dentárias de número são alterações comuns da dentição humana que podem interferir na harmonia do crescimento e desenvolvimento dento-facial. O diagnóstico precoce e o tratamento adequado destas alterações de desenvolvimento são essenciais para que uma harmonia oclusal, funcional e estética, possa ser estabelecida. Assim, este artigo relata a reabilitação funcional e estética um dente supranumerário conóide, localizado na região ântero-superior da maxila, de uma criança em idade pré-escolar. A reanatomização do elemento dental foi realizada através de restauração direta em resina composta nanoparticulada, uso do guia palatina de silicone de adição e isolamento relativo modificado. Este procedimento minimamente invasivo além de ser passível de ajustes posteriores, permite o perfeito controle da reabilitação realizada e possibilita o restabelecimento simultâneo estético-funcional e da auto-estima da criança. Entretanto, o tratamento não deve se limitar exclusivamente à técnica restauradora. Sendo fundamental a manutenção da saúde bucal e da integridade da forma do arco para que seja possível à transição correta da dentição decídua para a permanente, permitindo que o impacto do tratamento realizado contemple a ausência de alterações na dentição permanente.

Termos de indexação: Dente decíduo. Estética dentária. Reabilitação bucal. Dente supranumerário.

\section{INTRODUCTION}

In children tooth integrity is closely related to the preservation of occlusion, aesthetics, phonetics, and psychological and emotional wellbeing ${ }^{1}$. However, many factors may hinder the development of normal occlusion, correct teeth alignment, and a congruous relationship between adjacent and opposing teeth ${ }^{2}$.

Supernumerary teeth are among these factors. This is a common anomaly in human dentition that may compromise congruous dental and facial growth and development ${ }^{3}$. The origin of supernumerary teeth is controversial ${ }^{4-5}$. Supernumerary teeth may affect both dentitions, but the prevalence is lower in the primary dentition ${ }^{6}$. Although its prevalence in the primary dentition also differs by sex, this anomaly is more prevalent in the permanent dentition of males ${ }^{7}$. Supernumerary teeth occur more frequently in the anterior maxillary region ${ }^{3}$.

Imaging tests are considered the best way to detect the presence of this anomaly ${ }^{7}$ since there is a high percentage of unerupted and asymptomatic supernumerary teeth $^{8}$. Currently, the best method for finding unerupted teeth is volumetric computed tomography, but its high cost is prohibitive9.

\footnotetext{
${ }^{1}$ Escola de Aperfeiçoamento Profissional da Associação Brasileira de Odontologia, Seção Mato Grosso, Especialização em Odontopediatria. Cuiabá, MT, Brasil.

${ }^{2}$ Universidade Federal do Rio Grande do Sul, Faculdade de Odontologia, Departamento de Odontopediatria. Porto Alegre, RS, Brasil.

${ }^{3}$ Centro Universitário de Várzea Grande, Curso de Odontologia. Av. Dom Orlando Chaves, 2655, Cristo Rei, 78118-900, Várzea Grande, MT, Brasil. Crrespondência para / Correspondence to: GP MOI. E-mail: <gisele.pedroso.moi@gmail.com>.
} 
The treatment of patients with this anomaly may or may not involve supernumerary tooth extraction ${ }^{10}$. The therapy of choice varies according to the position of the supernumerary tooth on the arch and the presence or absence of associated disease processes 5 . Moreover, supernumerary teeth in the primary dentition may erupt and exfoliate naturally ${ }^{8}$. Nevertheless, this anomaly may be accompanied by aesthetic ${ }^{11}$ and occlusal ${ }^{5}$ changes, eruption failures and delays ${ }^{12}$, and even tumors ${ }^{3}$.

Considering that early diagnosis and appropriate treatment of development changes are essential for occlusal, aesthetic, and functional congruence, the objective of this article was to report a clinical case involving the functional and aesthetic rehabilitation of a supernumerary peg-shaped tooth in the anterior maxillary region of a preschooler.

\section{CLINICAL CASE}

A male Caucasian patient aged 5 years and 7 months visited the Pediatric Dentistry Clinic of the Professional Development School of the Brazilian Dentistry Association of Mato Grosso to extract a supernumerary peg-shaped tooth that had erupted in the anterior maxillary region (Figure 1).

During anamnesis the mother reported that when her child was about one and a half years old, he fell from his cousin's lap and hit his mouth on the corner of a table, and "the entire front tooth fell off." She also shared that a "strange tooth" erupted on the space of the lost tooth when the child was around four years old.

Clinical and radiographic examination (Figures 1 and 2) showed that the patient was in the primary dentition phase and had inactive caries lesions, no periodontal disease, and no upper left central incisor, which had been avulsed by the dento-alveolar trauma described by the mother during anamnesis, and an erupted, supernumerary peg-shaped tooth at the site.

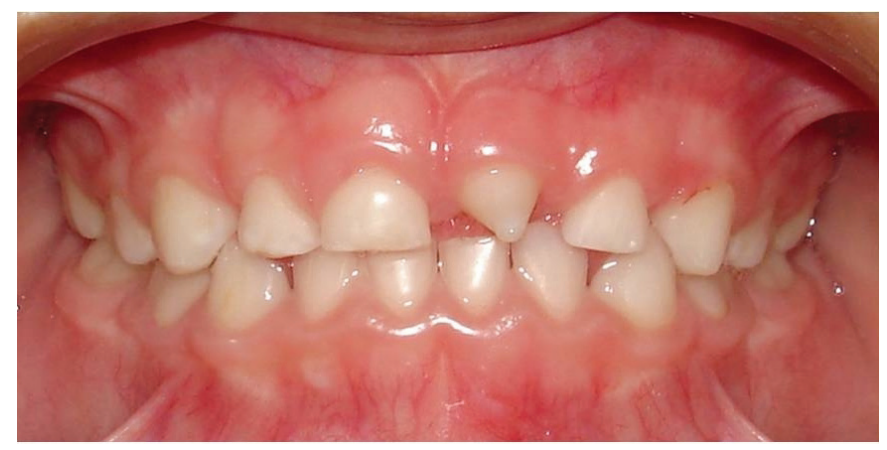

Figure 1. Initial clinical aspect: supernumerary peg-shaped tooth in the anterior maxillary region.

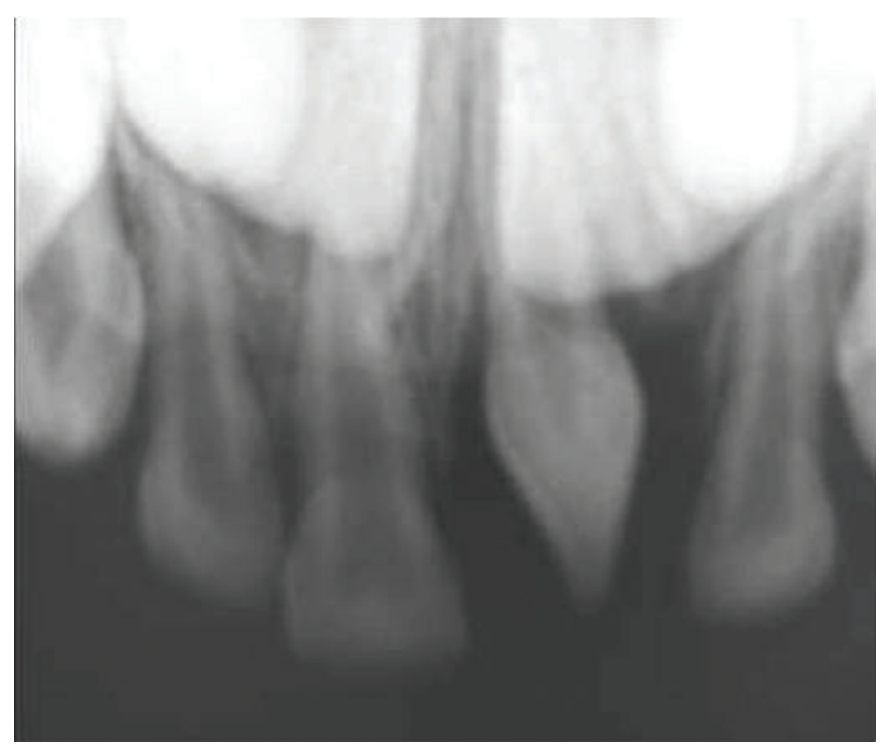

Figure 2. Radiographic aspect of the anterior maxillary region.

Given the child's craniofacial growth and development phase, the treatment attempted to reestablish symmetry and maintain dental arch congruence. Hence, the treatment plan consisted of turning the supernumerary peg-shaped tooth into an aesthetic and functional maxillary left central incisor. The treatment plan was then explained to the mother, who signed an informed consent form authorizing the treatment and the disclosure and publication of this clinical case.

Aesthetic and functional tooth correction included previous prophylaxis followed by enamel polishing with the discs Sof-Lex Pop-on ${ }^{\mathrm{TM}}{ }^{\circledR}$ (3M, Espe, Sumaré, Brazil) and diamond bur $\mathrm{FG}^{\circledR}$ 3195F (KG Sorensen, Cotia, Brazil), to align the tooth's anatomy with the dental arch (Figure $3 \mathrm{~A}-3 \mathrm{C}$ ), reestablishing its function and aesthetics (6A - 6F).
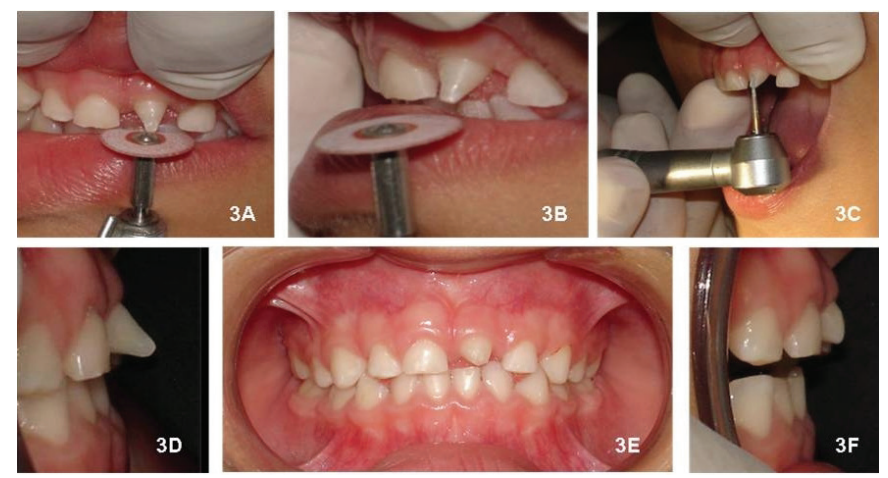

Figure 3. Preparation of the supernumerary peg-shaped tooth enamel with the polishing discs Sof-Lex Pop on ${ }^{\mathrm{TM}}{ }^{\circ}$ (3M, Espe, Sumaré, Brazil) and diamond bur FG ${ }^{\circledR} 3195 \mathrm{~F}$ (KG Sorensen, Cotia, Brazil) to align its shape with the dental $\operatorname{arch}(A-C)$, reestablishing its anatomy, function, and aesthetics (D-F). 
After making an impression of the patient's upper arch with Jeltrate alginate (Dentsply, Milford, DE, USA), a study cast was prepared using type III dental stone (Herodent ${ }^{\circledR}$, Vigodent, Rio de Janeiro, Brazil), and the supernumerary peg-shaped tooth received a diagnostic wax-up to visualize and define the final shape and contour of the restoration and to show the end result to the patient and his mother. The waxed-up cast was also used for creating a putty index (Express $X \mathrm{~T}^{\oplus}$, $3 \mathrm{M}$, Espe, Sumaré, Brazil) of the incisal position to guide the professional during the restorative stage (Figure 4A 4C). This putty accurately reproduces the lingual surface of the tooth, carefully planned and made in wax in the laboratory ${ }^{13}$.

After prophylaxis with pumice and water, the composite resin color was selected in the $V$ ita ${ }^{\circledR}$ scale (Vita Wilcos, Petropolis, Brazil). A pediatric lip retractor (Expandex ${ }^{\circledast}$, Indusbello, Londrina, Brazil) helped to hold a modified cotton roll isolation ${ }^{14}$ in place. The putty index of the incisal position was tested on the supernumerary peg-shaped tooth and used as a guide ${ }^{13}$.
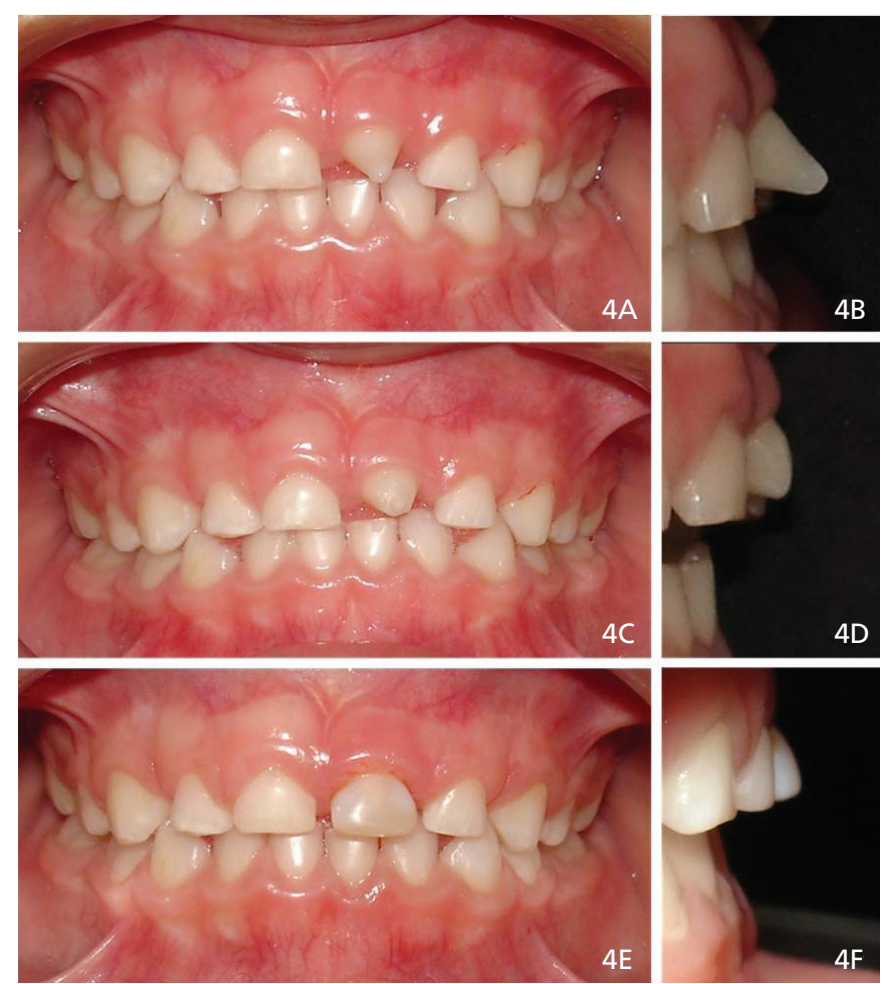

Figure 4. Initial clinical aspect of the supernumerary peg-shaped tooth in the anterior maxillary region: frontal view (4A) and lateral view (4B). Clinical aspect of the supernumerary peg-shaped tooth after preparation of the enamel, aligning its shape with the dental arch: frontal view (4C) and lateral view (4D). Final clinical aspect of the now functional and aesthetic supernumerary tooth after polishing and finishing the restoration: frontal view (4E) and lateral view (4F).
The enamel of the supernumerary tooth was etched with 35\% phosphoric acid (3M, Espe, Sumaré, Brazil) for 15 seconds $^{15}$ and rinsed with abundant water for another 15 seconds. The site was partly dried with a cotton ball and the adhesive Single Bond ${ }^{\circledR}$ (3M, Espe, Sumaré, Brazil) was applied as recommended by the manufacturer (Figure 5A - 5C).
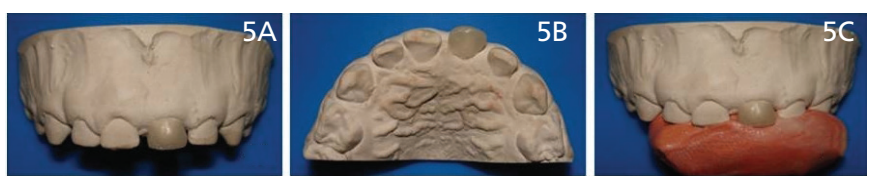

Figure 5. Diagnostic wax-up ( $A$ and $B$ ) and creation of the putty index of the incisal position using the addition silicone Express $X T^{\circledR}$ (3M, Espe, Sumaré, Brazil), which guides the professional during the restorative stage (C).

A small amount of the composite resin Filtek Supreme Plus ${ }^{\circledR}$ WB (3M, Espe, Sumaré, Brazil) was placed on the putty index, in the depression corresponding to the planned palatal enamel. The putty index was then positioned carefully to promote full contact between the resin and the tooth surface, creating a correct palatal anatomy (Figure 5D). The resin was then photopolymerized for 20 seconds. Once the palatal enamel was reconstituted with the aid of the putty index, a second layer of the resin Filtek Supreme Plus ${ }^{\circledR}$ A1B (3M, Espe, Sumaré, Brazil) was added to reconstitute the artificial dentin. Each increment was photopolymerized for 20 seconds. The last layers of the resin Filtek Supreme Plus ${ }^{\circledR}$ A1E (3M, Espe, Sumaré, Brazil) were added to reproduce the enamel, molded to the dental structure (Figure 5F) using brushes numbers 2 and 3 (Brushes, Cosmedent), and photopolymerized for 20 seconds. The excess was removed with a scalpel blade number 12 and the polishing discs Sof-Lex Pop $\mathrm{on}^{\mathrm{TM} \circledast}$ (3M, Espe, Sumaré, Brazil). The occlusal relationship of the reconstructed tooth was assessed by the occlusal marking film Accufilm ${ }^{\circledR}$ (Parkell Inc., Edgewood, NY, EUA) during centric occlusion and lateral and lateral protrusive movements. The tooth was finished in the next session using the abrasive rubber points and brushes Astropo ${ }^{\circledR}$ and Astrobrush ${ }^{\circledR}$ (Ivoclar Vivadent, Barueri, Brazil), respectively, creating a smooth and shiny surface (Figure $5 \mathrm{H}-5 \mathrm{l}$ ).

Once the aesthetic and functional transformation of the supernumerary tooth was complete, the mother and child received instructions on oral hygiene and maintenance of oral health.

The patient comes in every six months to assess the degree of exfoliation of the primary teeth and eruption of the permanent teeth; periodontal health; and control of caries disease (plaque control, diet, and rational fluoride use) to prevent the treatment from affecting the permanent dentition. 


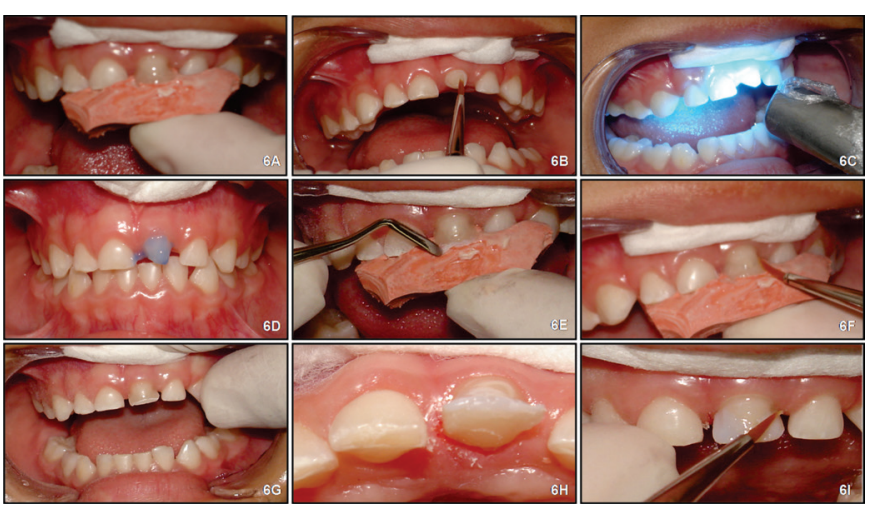

Figure 6. Acid etching with $35 \%$ phosphoric acid (3M, Espe, Sumaré, Brazil) for 15 seconds (6A); application of the conventional adhesive system Single Bond ${ }^{\circledast}(3 \mathrm{M}$, Espe, Sumaré, Brazil) and photopolymerization as recommended by the manufacturer $(\mathbf{6 B}$ and $\mathbf{6 C})$; addition of a thin layer of the resin FilteK Supreme Plus ${ }^{\circledast}$ WB (3M, Espe, Sumaré, Brazil) on the putty index Express $X \mathrm{~T}^{\oplus}$ (3M, Espe, Sumaré, Brazil), in the area corresponding to the planned palatal enamel and molding (6D), making sure that the resin contacts the dental surface fully and follows the palatal anatomy properly (6E); the artificial dentine and enamel were reconstructed with increments of the resins Filtek Supreme Plus ${ }^{\circledast} \mathrm{A} 1 \mathrm{~B}$ and $\mathrm{A} 1 \mathrm{E}$, respectively (3M, Espe, Sumaré, Brazil), and each increment was photopolymerized for 20 seconds (6F): immediate final aspect of the aesthetic and functional reconstruction of the supernumerary pegshaped tooth (6G - 6I).

\section{DISCUSSION}

The present clinical case discusses the functional and aesthetic rehabilitation of a supernumerary pegshaped tooth that erupted in the region corresponding to the maxillary left central incisor, which had been avulsed during a dento-alveolar toddlerhood trauma. Traumatic lesions in primary teeth are common occurrences in toddlerhood since it is during this time that toddlers begin walking but do not have the motor coordination to avoid falls ${ }^{16}$. These lesions may then trigger serious morphological, physiological, and emotional complications.

Early loss of the anterior maxillary primary teeth or the presence of dental anomalies in this region may lead to psychological problems and hinder children's selfesteem and socialization in an extremely important phase of their development ${ }^{17}$. The individual may have relationship difficulties, compromising student performance and increasing absences ${ }^{18}$. Although the biological cycle of the primary teeth in the oral cavity is finite, their presence is extremely important for mastication, articulation, phonation, and occlusion until normal exfoliation occurs ${ }^{19}$. Hence, teeth should be kept in the oral cavity until their exfoliation time for the congruous development of the child's stomatognathic system ${ }^{17}$. Additionally, children's occlusion, aesthetics, phonetics, and psychological and emotional wellbeing are closely related to the integrity of their teeth'.

Supernumerary teeth are common changes in human dentition that may affect the congruence of the dental and facial growth and development ${ }^{3}$, and early diagnosis is critical to minimize the risk of associated complications ${ }^{6}$. Treatment of these anomalies may or may not involve surgical extraction ${ }^{10}$, and this choice will depend on the position of the supernumerary tooth on the dental arch and the presence or absence of associated disease processes ${ }^{5}$. Another important fact to consider is that supernumerary primary teeth may undergo natural eruption and exfoliation ${ }^{8}$. On the other hand, this anomaly can also be associated with aesthetic ${ }^{11}$ and occusal ${ }^{5}$ changes.

The technological advance of composite resins and adhesive systems allows professionals more and more to use minimally invasive techniques ${ }^{20-21}$. Hence, aesthetic and functional transformation using these materials helps to reestablish the teeth's congruence and shape ${ }^{14}$. This work used a nanocomposite resin for the entire aesthetic and functional direct restoration of the peg-shaped tooth. This resinous material combines excellent mechanical properties (such as resistance to fracture and wear) with excellent surface smoothness, maximizing its aesthetic properties ${ }^{22-23}$. Moreover, the use of a putty index of the incisal position ${ }^{13}$ and modified cotton roll isolation ${ }^{14}$ for the restoration optimizes treatment time, something that should be taken into account in pediatric practice.

Despite the various techniques proposed for treating supernumerary teeth, the aesthetic and functional transformation of the erupted supernumerary peg-shaped tooth in the dental arch of this child was minimally invasive, showing that the surgical extraction of supernumerary teeth that do not affect dentition may not be necessary ${ }^{5}$ since these teeth may be present for years without pathological manifestations ${ }^{24}$. However, supernumerary teeth may delay or prevent eruption and eruption rotation, or even dislocate the succeeding permanent teeth in the dental arch, so follow-up is critical ${ }^{5}$.

\section{CONCLUSION}

Despite the various techniques proposed for treating supernumerary teeth, the direct restoration procedure to recover the aesthetics and function of the erupted supernumerary peg-shaped tooth on the dental arch was minimally invasive. Since a putty index of the incisal position and modified cotton roll isolation decrease restoration time, their use should be considered in pediatric practice. Additionally, this procedure can be adjusted later, allowing perfect control of the rehabilitation; and the 
reestablishment of the tooth's aesthetics and function, and the child's self-esteem. However, treatment should not be limited exclusively to the restorative technique. Oral health and arch integrity and shape are critical for the correct transition between primary and permanent dentitions, preventing the treatment from promoting changes to the permanent dentition.

\section{REFERENCES}

1. Judd PL, Kenny DJ, Johnston DH, Yacobi R. Composite resin short post technique for primary anterior teeth. J Am Dent Assoc. 1990;120(5):553-5.

2. Primo LG, Wilhelm RS, Bastos EPS. Freqüência e características dos dentes supranumerários em crianças brasileiras: conseqüências e tratamento propostos. Rev Odontol Univ São Paulo. 1997;11(4):231-7.

3. Santos APP, Ammari MM, Moliterno LFM, Capelli-Júnior J. First report of bilateral supernumerary teeth associated with both primary and permanent maxillary canines. J Oral Sci. 2009;51(1):145-50. doi: 10.2334/josnusd.51.145.

4. Garvey MT, Barry HJ, Blake M. Supernumerary teeth: an overview of classification, diagnosis and management. J Can Dent Assoc. 1999;65(11):612-6.

5. Chaves-Netto HDM, Assis NMSP, Nogueira B, Chaves MGAM, Vitral, RWF. Supernumerary teeth at primary and permanent dentition. Braz J Oral Sci. 2006;5(18):1112-8.

6. Rajab LD, Hamdam MAM. Supernumerary teeth: review of literature and survey of 152 cases. Int J Paediat Dent. 2002;12(4):244-53. doi: j.1365-263X.2002.00366.x.

7. Jacobs S. Radiographic localization of unerupted teeth: further findings about vertical tube shift method and other localization techniques. Am J Orthod Dentofacial Orthop. 2000;118(4):43947. doi: 10.1067/mod.2000.108782.

8. Zhu JF, Marcuchamer M, Kink DL, Henry RJ. Supernumerary and congenitally absent teeth: a literature review. J Clin Pediatr Dent. 1996;20(2):87-95.

9. Zöller EJ, Neugebauer J. Cone-beam volumetric imaging in dental, oral and maxilofacial medicine: fundamental, diagnostics and treatment planning. Germany: Quintescence Books; 2008.

10. Babu V, Nagesh KS, Diwakar NR. A rare case hereditary multiple impacted normal supernumerary teeth. J Clin Pediatr Dent. 1998;23(1):59-61.

11. Türkkahramam $H$, Yilmaz $H H$, Çetin $E$. A non syndrome case with bilateral supernumerary canines: report of a rare case. Dentomaxillofac Radiol. 2005;34(5):319-21. doi: 10.1259/ dmfr/25079119.

12. Hayduk JW, Stout RA. Bilateral supplemental deciduous canines with associated unilateral supernumerary permanent canine. Oral Surg Oral Med Oral Pathol. 1964;18(1):24-6. doi: 10.1016/0030-4220(64)90251-8.

\section{Collaborators}

D KHOURI, CAV BERTAIA, and FB ARAUJO helped to treat the patient and write the article. ES GARCIALEITE, PX COSTA, and RCF SANTOS supervised the clinical procedures and helped to write the article. GP MOI prepared and wrote the article.

13. Fellipe LA, Monteiro-Júnior S, De Andrada CA, Cerqueira A, Ritter AV. Clinical strategies for sucess in proximoincisal composite restorations. part II: application techinique. J Esthete Restor Dent. 2005;17(1):11-21.

14. Gondo R, Araujo-Júnior EM, Baratieri LN. Restaurações diretas de resina composta em dentes anteriores fraturados. Clín Int J Braz Dent. 2005;1(1):20-8.

15. van Meerbeek $B$, Peumans $M$, Verschueren $M$, Gladys $S$, Braem $M$, Lambrechts $P$, et al. Clinical status of ten dentin adhesive systems. J Dent Res. 1994;73(11):1690-702. doi: 10.1177/00220345940730110401.

16. Kawabata CM, Sant'Annai GR, Duarte DA, Mathias MF. Estudo de injúrias traumáticas em crianças na faixa etária de 1 a 3 anos no município de Barueri, São Paulo, Brasil. Pesq Bras Odontoped Clin Integr. 2007;7(3):229-33.

17. Mattuella LGM, Frasca LCF, Bernardi L, Moi GP, Fossati ACM, Araujo FB. Tooth supported prosthetic rehabilitation in a 5-year-old child with early childhood caries. J Clin Pediatr Dent. 2007;31(3):173-6.

18. Feitosa $S$, Colares V. As repercussões da cárie precoce na infância na qualidade de vida de pré-escolares. Rev Ibero-Am Odontopediatr Odontol Bebê. 2003;6(34):542-8.

19. Nogueira AJS, Gillet AVM, Parreira EB, Pedreira EN, Athayde Neto MD. Perdas precoces de dentes decíduos e suas conseqüências para dentição futura: elaboração de propostas preventivas. Rev ABO Nac. 1998;6(4):228-33.

20. Mount GJ, Ngo H. Minimal intervention: a new concept for operative dentistry. Quintessence Int. 2000;31(8):527-33.

21. Figueiredo RJA, Andrade AKM, Duarte RM, Medeiros e Silva FDSC. Otimizando a estética por meio de reanatomozações em dentes conóides. RGO - Rev Gaúcha Odontol. 2007;56(3):333-6.

22. Pontes AP, Mainieri ET, Pacheco JFM, Martins JL, Shinkai RAS, Mainieri VC. Rugosidade superficial de compósitos microparticulados e nanoparticulados após acabamento e polimento. RGO - Rev Gaúcha Odontol. 2009;57(2):179-82.

23. Lee $Y-K, L U$ H, Powers JM. Measurement of opalescence of resin composites. Dent Materials. 2005;21(11):1068-74. doi: 10.1016/j.dental.2005.03.015.

24. Khalaf K, Robinson DL, Elcock C, Smith RN, Brook AH. Tooth size in patients with supernumerary teeth and a control group measured by image analysis system. Arch Oral Biol. 2005;50(2):243-8. doi: 10.1016/j.archoralbio.2004.09.013.

Received on: 16/11/2010

Final version resubmitted on: 26/6/2011

Approved on: 19/10/2011 